\title{
Painting as an open window to brain disorders
}

Keywords: painting, neurosciences, brain disorders, epilepsy, movement disorders, dementia, art

\section{Editorial}

Neurology is a very expressive science. It is widely depicted in paintings and sculptures. It is revealed in poems and fiction and it is brightly appeared, in an eloquent way in Philosophy and Music, from the antiquity to our Era.

The language of the art is plenty of aesthetical Ideas, as Kant claimed, ${ }^{1}$ which are transmitted by creation of the art and received by perception. Painting is particularly a wide window viewing into human brain and soul, visualizing and projecting consequently a large number of functions and processes of the brain cortical and subcortical areas, uncovering many dysfunctions and brain disorders. In reality, painting is a boundless flexible mystic language of creative beauty, expressing thoughts and emotions, observations and feelings, facts and imaginations as well as many interior psychological events of the artists, who endeavor to exteriorize themselves by visual art creations, allowing the observers to participate in their own interior phenomena and cognitive processes. ${ }^{2}$

The aesthetic preferences of the artist depend upon his cultural background as well as his training and experience. However, a substantial body of evidence advocate in favor of a biological basis of some aesthetic preferences. The perception of painting, on the other hand, involves extensive neuronal circuits in the brain, which are extended widely at cortical and subcortical level. The center of vision in the occipital lobe perceives the information of the picture and collaborating with the temporal, parietal, frontal lobes and the thalamus attempts to understand the meaning as well as the emotional and philosophical message of the artist. ${ }^{3}$

Thus in the field of Neurosciences painting possess a valuable position in the interpretation of the mental and psychic condition of artists, who suffered from the dramatic functional alteration due to neurological or psychiatric disorders. ${ }^{4}$

In addition, painting reveals the cerebral lateralization ${ }^{5}$ as well as the way that a neurological disease modify the perception and suppress or rarely increase the creativity of the artist. ${ }^{6,7}$ The observation of a picture may also revive memories or generate ideas of similar subjects, which through symbolism may reveal feelings and thoughts of existential importance for the artist. ${ }^{8}$ Sometimes the message of a painting is obscure or very complicated and needs high intelligence in order to be precisely decoded. In a substantial number of neurological diseases the style of painting, the choice of colors, ${ }^{9}$ as well as the thematic expression are deeply influenced by the morbid and even the premorbid personality of the artist.

Diseases with neurological phenomenology such as poliomyelitis are shaped in sculptures or anaglyphs even in ancient Egypt since the 19 dynasty, as it is seen in the funeral stele of the priest Ruma (Ny Carlsberg Glyptothek of Copenhagen), whose the right leg is apparently atrophied and shorter than the left one.

Neurological disorders, such as the facial nerve palsy and its consequences on face's mimic expression are rather common subjects in visual arts, as that was portrayed in the Cathedral of Trondheim in
Volume 10 Issue 3 - 2020

\author{
Stavros J Baloyannis \\ Professor Emeritus, Research Institute for Alzheimer's disease, \\ Aristotelian University, Greece
}

Correspondence: Stavros J Baloyannis, Professor Emeritus, Aristotelian Univesity, Angelaki 5, Thessaloniki 54621, Greece, Tel +3023 I0270434, Fax +3023I0270434 Email sibh84@otenet.gr

Received: June 01, 2020 | Published: June 04, 2020

the 12th century (representative of "syke skulpturen"), as well as in St. Thomas' church in Strasbourg in the 15th century.

Parkinson's disease has been frequently portrayed in paintings, since the first drawings by Paul Richer, in Salpetriere, demonstrating the stooped posture and the rigid positioning of the upper and lower extremities of a patient suffered from Parkinson's diseases.

Albrecht Dürer (1471-1528) also depicted the rigidity and the face's emotionless expression of persons suffered presumably from Parkinson's disease, long before this entity was described by James Parkinson (1755-1824). Dürer in his self-portrait in 1500 (Alte Pinakothek, Munich) painted himself with a rigid apathy face, as suffering from Parkinson's disease. Jules-Alexandre Grun (1868-934) who suffered from Parkinson's disease, gave a concrete pictorial description of his disease in the posture of the bodies and the emotionless faces. Adolf Hitler (1889-1945), who was also a painter used to draw places of Vienna and other central European cities, during his premorbid life, depicting the human silhouettes rigid and motionless. Later on he started suffering from Parkinson's disease, ${ }^{10,11}$ which aggravated continuously reaching to a pic at the end of his life, when he committed suicide.

Pieter Bruegel painted very expressively the association of facial dystonias with motor inability of the lower limbs. In some of Pieter Bruegel paintings the motor disorders of the lower limbs are associated with oromandibular dystonia as it is showed in "The Beggars" (1568). Oromandibular dystonia is expressively depicted in the "Portrait of an Old Woman, 1563" (Alte Pinakothek, Munich) and Meige's syndrome (blepharospasmus) is well depicted in Bauernfrau (1564-1566) (Rijksmuseum, Amsterdam). Pieter Bruegel described also in his paintings an unusual type of chorea, as "Saint Vitus' dance" (Chorea Sancti Viti), ${ }^{11}$ which might be minor chorea or Sydenham's, which appeared in Central Europe in the sixteen century. In his drawing in a pen and ink etitled " Die Epileptikerinnen von Meulebeeck “ (1564) ( Bibliothèque royale Albert Ier,Cabinet des Estampes, Brussels, Belgium) he depicted a group of women in dancing, hysteric or epileptiform positions, which was a common phenomenon in those Era.

Hemiplegic's gait has been realistically depicted by Jacque Callot (1592-1635), a "prolific and versatile graphic artist" who introduced many technical innovations and created over 1,400 prints during 
his short life. In one of his pictures entitled "Beggar with Crutches and Hat, Back View" (National Gallery of Art, Washington DC) the beggar has a typical hemiplegic posture of his right lower limb and attempted to walk supported by crutches.

Epilepsy possess a substantial place in pictorial art. Probably the most expressive picture describing epileptic seizures is "The transfiguration" (Vatican Museum) by Raffaello Santi (Urbino 1483Rome1520), completed just before his death on Good Friday in 1520. In this painting a child in view of the transfiguration of the Lord has had an epileptic attack with oculogyric crisis, hyperextension of the hands and fingers and torsion of the body, in front of the wondering and anxious eyes of the people. In addition, in a painting by Peter Paul Rubens (Siegen 1577- Antwerpen 1640) entitled "The Miracles of St. Ignatius of Loyola" (1620) an Altarpiece, we would notice that among the patients who pleaded for mercy and treatment epileptics were also in seizures.

Vincent van Gogh (Groot-Zundert 1853- Auvers-sur-Oise 1890) an epileptic himself, whose life was full of commitments of selfmutilations, described in his pictures the epileptic face and the epileptic perception, "painting in brilliant colors, well arranged, resplendent" [13]. He used to have several types of epileptic crisis' including grand mal attacks and temporal lobe epileptic phenomena [14]. Once, when van Gogh was in post ictus condition cut off his auricle and few weeks later in January, 1889, he started painting his self-portrait, showing obviously his disfigurement with his right ear bandaged, whereas in reality he mutilated his left ear (Self-Portrait with Bandaged Ear,1889 The Courtauld Gallery, London).

Temporal lobe epilepsy is well pictured among the others by Giorgio de Chirico (1888-1978), one of the most distinguished precursors of Surrealism of the twentieth century, 'inventor' of metaphysical painting, ${ }^{15}$ who suffered himself presumably from epilepsy. ${ }^{16}$

Visual experiences, such as heavenly visions, perceptions in open view of falling sparks and ecstatic states have been described by Hildegard von Bingen (1098-1179), a famous German nun, artist, music composer, poet and author of theologian dissertations, who exersised an important influence on the mysticism of the 12th century, known as Sybil of Rein. She suffered from migraine and described her migraine attacks either in paintings or in literature ("Scivias" and "Liber vitae meritorum"). ${ }^{17,18}$

The spinal cord and spinal column injuries were very emotionally described by the Magdalena Carmen Frida Kahlo y Calderon (19071954), a Mexican political activist, and painter, who suffered from poliomyelitis at the age of six and got a fracture of the spinal column in 1925, at the age of eighteen, due to a traffic accident. Her long suffering, in a revolutionary period of Mexican history, exercised a strong influence on her artistic creativity, which was mostly focused on her physical incapacities. ${ }^{19}$ Her struggle against lifelong chronic pain, depression, emotional and psychological traumas, invalidism and alcohol abuse was clearly appeared in her paintings. ${ }^{20}$ Her art is the visualization of a tragic intimate story, plenty of painful experiences and disappointing. ${ }^{21}$ She claimed that her pictures revealed her own reality as it is paradigmatically depicted in the painting entitled "The Broken Column, 1944 (Museo Dolores Olmedo Patino, Mexico City). ${ }^{22}$

Dementia, particularly Alzheimer's disease, imposes its traces on paintings very early . Large number of painters who suffered from
Alzheimer's disease were affected by delusions and demonstrated spatial errors and defective colour-perception in the course of disease $\mathrm{e}^{23}$ In addition most of them have an incapacity in drawing the face and giving a proper emotional expression. Thus the face frequently has a childish appearance, as it is clearly seen in the paintings of Carolus Horn (1921-1992), a German well known graphic artist and illustrator, who contracted with $\mathrm{AD}$ and continued to work for long time before his death, though the artworks became very simple, the colors were faint or pale and the images became progressively twodimensional. The same color and shape alterations are seen in the paintings of Willem de Kooning (1904- 1997), who simplified his art capability tremendously as the disease advanced. In the case of William Utermohlen (1933-2007), his paintings were oversimplified in the advanced stages of Alzheimer's disease showing a marked lack of symmetry, proportion and perspective..$^{24,25}$

Fractal analysis can detect the changes of artistic capability which may occur even in the initial stage of dementia differentiating normal ageing from dementia. ${ }^{26}$ It is important that some artists expressed an increased creativity in painting during their course in dementia as it is well demonstrated in the paintings of Danae Chambers, who despite of her declined cognition continued to paint with enduring creativity, whilst she was experiencing a serious loss of memory and attention. ${ }^{27}$

In conclusion pictorial art provides a unique way for exteriorization of emotions and feelings of the artist as well as his psychological and mental processes. In addition it offers the possibility for an interaction between the artist's mystical language and the observer's capacity to perceive the language and to generate and develop his own emotions. The study of the artworks by the neurologist offers the possibility to detect neurological disorders in the initial stages, at a time when clinical phenomena and functional impairment of the patients are minimal or inexistent.

\section{Acknowledgments}

None.

\section{Conflicts of interest}

The authors declare no conflicts of interest.

\section{References}

1. Wicks R. Kant on fine art: Artistic sublimity shaped by beauty. The Journal of aesthetics and art criticism.1995;53(2):189-193.

2. Baloyannis SJ. Neurology in pictorial arts. Encephalos. 2007;44(1):1-24.

3. Zeki S. Essays on science and society. Artistic creativity and the brain. Science. 2001;293(5527):51-52.

4. Stien R: Hjernen og kunsten. Nevrolitteraere klubb. Oslo 2001.

5. Grusser O, Selke T, Zynda B. Cerebral lateralization and some implications for art, aesthetic perception, and artistic creativity. Beauty and the Brain. Basel, Germany, Birkhauser Verlag. 1988.

6. Carota A, Staub F, Bogousslavsky J. Emotions, behaviours and mood changes in stroke. Curr Opin Neurol. 2002;15:57-69.

7. Heilman K, Nadeau S, Beversdorf D. Creative innovation: possible brain mechanisms. Neurocase. 2003;9(5):369-379.

8. Goodman N. Language of art: an approach to a theory of symbols. Indianapolis. Hacket Publications. 1976.

9. Blanke O, Ortigue S, Landis T. Color neglect in an artist. Lancet. 2003;361:264. 
10. Gerstenbrand F, Karamat E. Adolf Hitler's Parkinson's disease and an attempt to analyse his personality structure. Eur J Neur. 1999;6(2):121127.

11. Baloyannis SJ, Some issues on the profile of the premorbit personality of patients suffered from Parkinson's disease. Int Psychogeriatr. 2005; 17:333-334.

12. Palacios-Sánchez L, Botero-Meneses JS, Tierradentro-García LO, Saint Vitus of Lucania: Patron Saint of chorea. Medicina. 2018;40(3):349-353.

13. Voskuil PHA. Vincent van Gogh's malady: a test case for the relationship between temporal lobe dysfunction and epilepsy? J History of the Neurosciences. 1992;1(2):155-162.

14. Lin Hsinmei. Starry Nights: Whitman, Epilepsy, and Van Gogh. Walt Whitman Quarterly Review 2019;36(2):179-201.

15. Bogousslavsky J. The last myth of Giorgio De Chirico: neurological art. Front Neurol Neurosci. 2010;27:29-45.

16. Podoll K, Nicola U. The illness of Giorgio de Chirico--migraine or epilepsy? Eur Neurol. 2004;51(3):186-187.

17. King-Lenzmeier, Anne H. Hildegard of Bingen: an integrated vision. Collegeville, Minn: Liturgical Press. 2001.

18. Maddocks Fiona. Hildegard of Bingen: the woman of her age. Doubleday, 2001.
19. Herrera H. Frida: A Biography of Frida Kahlo. New York: Harper \& Row Publishers. 1983

20. Courtney CA, O 'Hearn MA, Franck CC. Frida Kahlo: portrait of chronic pain. Physical therapy. 2017;97(1): 90-96.

21. Budrys V. Neurological deficits in the life and works of Frida Kahlo. European neurology. 2006;55(1):4-10.

22. Feldman GC. Dissociation, repetition-compulsion, and the art of Frida Kahlo. J Am Acad Psychoanal. 1999;27(3):387-396.

23. Maurer K, Prvulovic D. Paintings of an artist with Alzheimer's disease: visuoconstructural deficits during dementia. J Neural Transm. 2004;111:235-245.

24. Crutch SJ, Rossor MN. Artistic changes in Alzheimer's disease. International Review of Neurobiology. 2006;74:147-161.

25. Harrison EM. Understanding suffering: Utermohlen's self-portraits and Alzheimer's disease. Nurse educator. 2013;38(1):20-25.

26. Forsythe A, Tamsin W. What Paint Can Tell Us: A fractal analysis of neurological changes in seven artists. Neuropsychology. 2017;31(1):1-10.

27. Fornazzari LR. Preserved painting creativity in an artist with Alzheimer's disease. Eur J Neurol. 2005;12(6):419-424. 